\section{THE HOPE AND RESULT OF AMERICAN EDUCATION}

"Education is the best possible preparation for war, if wars must come; it is the only sure preparation for universal brotherhood and world-peace," declared President Charl Williams, of the National Education Association, in an address before the National Council of Educators in session in Chicago, February 27. Miss Williams in speaking of inequalities in American education said, "When the average has been struck for the nation, the country boy or girl has just one half the chance to become educated as has the child in the city." Miss Williams made a strong plea for better financial support of education, higher salaries for teachers and the equalization of educational opportunity throughout the nation. Her speech in part follows:

The educational purpose of our nation unfolded slowly although education is inherent in the very word democracy, the two being interdependent and inseparable. However, when we contrast the early colonial school, local or private in its concern, discriminating between the needs of the poor and the rich with our present-day conception of public education with its equality of opportunity to all races and creeds alike, it is a cause for transcendent pride and inspiration for greater achievements. No other nation on earth has set up for itself this principle of universal education-the essential difference comes through our democracy.

This is true in theory, but as a matter of fact there are gross inequalities of opportunity offered the children of America today. When the average has been struck for the Nation it has been estimated that the country boy or girl has just about one-half the chance to become educated as has tive city child, due to short school terms, immature, untrained, poorly paid teachers, lack of compulsory attendance, and little or no supervision.

It has become a trite saying that the life and strength of a democracy is in direct ratio to the enlightenment of its citizenry, and it has never been challenged. When this simple truth finds lodgment in the hearts of all our people, there will be given to the great American educational scheme a force and direction never felt before. Having performed but once the duties and responsibilities of a full-fledged citizen of this republic, I am profoundly impressed with the enormousness of our task and the sacredness of our obligations.

There rests upon the teaching professinn in this country today a responsibility so ser ious in its nature, so far-reaching in its consequences that it staggers the imagination of our leaders and challenges the best efforts which the united profession can bring to bear upon it.

It is a task of sufficient magnitude alone to set out to mobilize the mental, moral, and physical resources of this great countrybut that even is not the end. Whether we will it, or not, the hopes and aspirations of all of the nations of the earth are centered in us, the freest of all people. We cannot regard this trust lightly. America is still the world's great leader in democracy, and we must so shape our affairs at home and dircet our policies abroad that these yearnings of peoples everywhere may find satisfaction and peace and confidence in the leadership which we have given to them.

It is right and proper and a sign of hope that the great nations of the earth have sat down together to devise some plan for international arbitration and for the elimination of some of the causes of war. Whatever the scheme devised may be, when the councils have disbanded, and their work has been given to the world, the task is only begun, for no plan will be stronger than the public sentiment and moral sense of humanity. If their work is to endure and is to be followed by greater steps toward world-peace, then the great teaching agencies of the earth - the schools, the press, the pulpit-must begin their work. The children of one country do not hate the children of another country unless they are taught to do so. The great mind and heart of the world cherish goord will and abhor war.

That the peoples of the earth may develop to the limits of their possibilities, this development to be based upon a right and just and honorable understanding among them, is education's chief task and here lies America's golden opportunity. Education is the best possible preparation for war, if wars must come; it is the only sure preparation for universal brotherhood and worldpeace. 